\title{
PENGARUH KOMPENSASI NON FINANSIAL, DISIPLIN KERJA DAN MOTIVASI TERHADAP KINERJA PEGAWAI DI KEMENTERIAN AGAMA KABUPATEN DONGGALA
}

\author{
I Dewa Putu Ardiana \\ Syahir Natsir \\ Yoberth Kornelius \\ Jurusan Manajemen, Fakultas Ekonomi, Universitas Tadulako \\ Email: dewablue002@gmail.com
}

\begin{abstract}
This study intends to determine and analyze simultaneous influence of non-financial compensation, work discipline, and motivation on the performance of employees in the Ministry of Religious; determine and analyze partial influence of non-financial compensation on the performance of employees in the Ministry of Religious; determine and analyze partial influence of work discipline on the performance of employees in the Ministry of Religious; determine and analyze partial influence of motivation on the performance of employees in the Ministry of Religious. Regression test results obtain sig. $F$ value of $0.000<0.05$, which can be interpreted that work discipline and motivation simultaneously have significant influence on employee performance; significance level of $t$-value of non-financial compensation of $0.798>0.05$ can be interpreted that non-financial compensation partially has non-significant influence on employee performance; the significance level $t$-sig. of 0,007 $<0,05$ means that work discipline partially has significant influence on employee performance; the significance level $t$-sig. of $0.034<0.05$ can be interpreted that motivation partially has significant influence on employee performance.
\end{abstract}

Keywords: non-financial compensation, work discipline, motivation, and performance.

ABSTRAK
Tujuan penelitian ini untuk mengetahui dan menganalisis apakah Kompensasi Non Finansial, Disiplin Kerja dan Motivasi secara simultan berpengaruh signifikan terhadap kinerja pegawai Kementerian Agama. Untuk mengetahui dan menganalisis apakah Kompensasi Non Finansial secara parsial berpengaruh signifikan terhadap kinerja pegawai di Kementerian Agama. Untuk mengetahui dan menganalisis apakan disiplin Kerja secara parsial berpengaruh signifikan terhadap kinerja pegawai di Kementerian Agama. Untuk mengetahui dan menganalisis apakan Motivasi secara parsial berpengaruh signifikan terhadap kinerja pegawai di Kementerian Agama. Berdasarkan hasil uji regresi diperoleh sig. F sebesar $0,000<0,05$, yang dapat diartikan bahwa kompensasi non finansial, disiplin kerja dan motivasi secara simultan berpengaruh signifikan terhadap kinerja pegawai. Kompensasi non finansial memiliki tingkat signifikasi t sig. $0,798>0,05$, yang dapat diartikan bahwa variabel Kompensasi Non Finansial secara parsial berpengaruh tidak signifikan terhadap kinerja pegawai. Disiplin kerja memiliki tingkat signifikasi t sig. 0,007 <0,05, yang dapat diartikan bahwa variabel disiplin kerja secara parsial berpengaruh signifikan terhadap kinerja pegawai. Motivasi memiliki tingkat signifikasi t sig. $0,034<0,05$, yang dapat diartikan bahwa variabel motivasi secara parsial berpengaruh signifikan terhadap kinerja pegawai.

Kata Kunci: Kompensasi Non Finansial, Disiplin Kerja, Motivasi dan Kinerja.

\section{PENDAHULUAN}

Kinerja adalah gambaran mengenai tingkat pencapaian, pelaksanaan tugas dalam suatu organisasi dalam upaya mewujudkan sasaran, tujuan, misi dan visi organisasi tersebut (Bastian 2001, dalam Siti aminah 2017). Melalui observasi yang dilakukan di Kementerian Agama Kabupaten Donggala, dengan mewawancarai seorang pegawai berinisial WT, beliau menjelaskan bahwa kinerja pegawai dalam melakukan tugasnya pada satu tahun terakhir ini masih kurang maksimal. Hal ini di karenakan peraturan kantor yang masih sering di langgar oleh pegawai. seperti, masih berada di kantin kantor 
saat jam istirahat sudah habis, dan masih adanya pegawai yang duduk- duduk di luar ruangan sambil merokok saat jam kerja belum habis.

Kompensasi non finansial adalah kepuasan kerja yang terdiri dari kepuasan yang diperoleh seseorang dari pekerjaan itu sendiri, atau dari lingkungan psikologis, dana tau fisik dimana orang itu bekerja. Dengan demikian dapat dijelaskan bahwa kompensasi non finansial merupakan kompensasi yang dapat diwujudkan dalam bentuk pendekatan lewat perhatian yang dapat membuat bangga karyawan (Simamora, 2006:444).

Melalui observasi yang dilakukan di kantor Kementerian Agama Kabupaten Donggala, peneliti mewawancarai seorang pegawai dengan inisial WT, yang menjelaskan bahwa lingkungan pekerjaan yang ada masih kurang nyaman terutama dalam ruang kerja, beliau menjelaskan bahwa ruang kerja yang ada belum memenuhi keinginan pegawai. Karena, menurutnya dalam satu ruangan yang terdiri dari empat orang di dalamnya masih belum bisa menciptakan rasa nyaman saat bekerja.

Disiplin Kerja sangat penting karena dengan pegawai mempunyai disiplin kerja maka akan menghasilkan kualitas kerja, kuantitas kerja dan waktu kerja yang baik sehingga dapat meningkatkan kinerja pegawai. Heidjrachman dan Husnan (2002:15) mengungkapkan disiplin adalah setiap perseorangan dan kelompok yang menjamin adanya kepatuhan terhadap perintah dan berinisiatif untuk melakukan suatu tindakan yang di perlukan seandainya tidak ada perintah.

Hasil observasi yang dilakukan di Kementerian Agama Kabupaten Donggala dengan mewawancarai seorang pegawai dengan inisial WT, menjelaskan bahwa disiplin kerja karyawan masih kurang maksimal, hal ini dilihat dari masih adanya pegawai yang berada di kantin kantor saat jam istirahat sudah habis. Hal ini di karenakan kurangnya kedisiplinan yang dimiliki pegawai dan masih kurangya keinginan untuk meningkatkan kualitas kerja yang dimiliki pegawai itu sendiri.

Motivasi adalah semangat atau dorongan dalam diri seseorang untuk melakukan kegiatan tertentu guna mencapai suatu tujuan yang dapat berpengaruh positif terhadap kinerja (Simanjutak dan Calam, 2012:3). Melalui obserpasi yang dilakukan di kantor Kementerian Agama Kabupaten Donggala, dengan mewawancarai pegawai yang sebelumnya sudah banyak memberikan informasi tentang kompensasi non finansial, kinerja dan disiplin kerja, beliau juga memberikan informasi tentang pemberian motivasi di kantor Kementerian Agama Kabuten Donggala. Salah satu penjelasan terkait dengan motivasi adalah masih rendahnya motivasi intrinsik atau motivasi yang berasal dari dalam diri pegawai, hal ini di lihat dari masih adanya pegawai yang berada di kantin saat jam istirahat sudah selesai. Hal ini menunjukan bahwa masih adanya pegawai kurang mendapatkan motivasi sehingga pegawai belum bisa memotivasi diri mereka.

Berdasarkan uraian tersebut, maka peneliti tertarik untuk melakukan penelitian di Kantor Kementerian Agama Kabupaten Donggala dengan tujuan untuk:

1. Mengetahui pengaruh kompensasi non finansial, disiplin kerja dan motivasi secara simultan terhadap kinerja pegawai di Kementerian Agama Kabupaten Donggala

2. Mengetahui pengaruh kompensasi non finansial secara parsial terhadap kinerja pegawai di Kementerian Agama Kabupaten Donggala

3. Mengetahui pengaruh disiplin kerja secara parsial terhadap kinerja pegawai di Kementerian Agama Kabupaten Donggala

4. Mengetahui pengaruh motivasi secara parsial terhadap kinerja pegawai di Kementerian Agama Kabupaten Donggala

\section{KAJIAN LITERATUR DAN PENGEMBANGAN HIPOTESIS Kompensasi Non Finansial}

Menurut Simamora (2007:120) kompensasi non finansial terbagi menjadi dua yaitu:

1. Kompensasi yang berhubungan dengan pekerjaan, kompensasi ini dapat berbentuk seperti pemberian tugas- tugas yang menarik, tanggung jawab, penghargaan, dan sebagainya. 
2. Kompensasi berhubungan dengan lingkungan pekerjaan, kompensasi ini terdiri dari kerabat kerja yang menyenangkan, lingkungan kerja yang nyaman, supervisi yang kompeten dan sebagainya.

\section{Disiplin Kerja}

Menurut Hasibuan (2005:194-198), dasarnya banyak indikator yang mempengaruhi tingkat kedisiplinan karyawan suatu organisasi, diantaranya adalah:

1. Tujuan dan Kemampuan

Tujuan dan kemampuan ini mempengaruhi tingkat kedisiplinan karyawan. Tujuan yang akan dicapai harus jelas dan ditetapkan secara ideal serta cukup menantang bagi kemampuan karyawan. Hal ini berarti bahwa pekerjaan yang dibebankan kepada karyawan harus sesuai dengan kemampuan karyawan yang bersangkutan agar karyawan dapat mengerjakanya. Akan tetapi jika pekerjaan itu diluar kemampuanya atau jauh dibawah kemampuanya maka kesungguhan dan kedisiplinan karyawan menjadi rendah. Disinilah letak pentingnya axas theright man in the right place and the right man in the right job.

2. Teladan Pimpinan

Teladan pimpinan sangat berperan dalam menentukan kedisiplinan karyawan karena pimpinan dijadikan teladan dan panutan oleh para bawahanya. Pimpinan harus memberi contoh yang baik, berdisiplin baik, jujur, adil, serta sesuai dengan perbuatan. Dengan teladan pemimpin yang baik kedisiplinan bawahan akan ikut baik, jika teladan pimpinan kurang baik para bawahanpun akan kurang disiplin. Pimpinan harus mempunyai kedisiplinan yang baik agar para bawahan pun mempunyai kedisiplinan yang baik pula.

3. Balas Jasa

Balas jasa berperan penting untuk menciptakan kedisiplinan karyawan artinya semakin besar balas jasa semakin baik kedisiplinan karyawan. Sebaliknya, apabila balas jasa kecil kedisiplinan karyawan semakin rendah. Karyawan sulit untuk berdisiplin baik selama kebutuhan-kebutuhan primernya tidak terpenuhi dengan baik.

4. Keadilan

Keadilan ikut mendorong kedisiplinan karyawan, karena ego dan sifat manusia yang selalu merasa dirinya penting saat meminta diperlakukan sama dengan manusia lainya. Keadilan yang dijadikan dasar kebijakan dalam pemberian balas jasa atau hukuman akan tercipta kedisiplinan yang baik. Manajer yang baik dalam memimpin selalu berusaha bersikap adil kepada semua karyawanya. Dengan keadilan yang baik akan tercipta disiplin yang baik pula.

5. Waskat (Pengawasan Melekat)

Waskat adalah tindakan nyata paling efektif dalam mewujudkan kedisiplinan karyawan perusahaan. Dengan waskat berarti atasan harus aktif dan langsung mengatasi perilaku, moral, sikap, gairah kerja dan prestasi kerja bawahannya.

6. Sanksi Hukuman

Sanksi hukuman berperan penting dalam memelihara kedisiplinan karyawan. Dengan sanksi hukuman yang lebih berat, karyawan akan semakin takut melanggar peraturan-peraturan perusahaan. Berat atau ringan sanksi hukuman yang diterapkan ikut mempengaruhi baik buruknya kedisiplinan karyawan.

7. Ketegasan Pimpinan

Ketegasan pimpinan dalam melakukan tindakan yang mempengaruhi kedisiplinan karyawan perusahaan, pimpinan harus berani dan tegas bertindak untuk memberikan sanksi kepada karyawan sesuai dengan yang telah ditetapkan perusahaan sebelumnya. Pimpinan dapat memelihara kedisiplinan karyawan yang ada dalam perusahaan. 


\section{Motivasi}

McClelland dalam (Bangun, 2012:325), menyatakan bahwa seseorang bekerja memiliki energi potensial yang dapat dimanfaatkan tergantung pada dorongan motivasi, situasi, dan peluang yang ada. McClelland membagi motivasi menjadi tiga, yaitu motivasi berprestasi, motivasi berkuasa, dan motivasi afiliasi.

1. Motivasi Berprestasi (Achievement)

Motivasi berprestasi tercermin dalam mencapai tujuan organisasi. Seorang yang mempunyai motivasi berprestasi akan menyukai pekerjaan yang menantang. Mereka menyukai pekerjaan yang cukup sulit, menantang, dan realistis. Mereka percaya kepada kemampuanya sendiri dalam mengerjakan pekerjaanya untuk mencapai sesuatu yang diharapkan. Mereka tidak terlalu mengharapkan bantuan orang lain dalam mengerjakan pekerjaanya melainkan yakin terhadap kemampuanya sendiri.

\section{Motivasi Berkuasa (power)}

Orang-orang yang memiliki kebutuhan yang tinggi untuk berkuasa akan menaruh perhatian besar dalam mempengaruhi dan mengendalikan orang lain dalam organisasi. Orang-orang seperti itu mempunyai hasrat untuk mempengaruhi dan mengendalikan orang lain dalam organisasi untuk mencapai tujuanya. Pada umumnya, orang- orang yang memiliki tingkat kebutuhan yang tinggi terhadap kekuasaan lebih menyukai situasi dimana mereka dapat memperoleh dan mempertahankan pengendalian sarana untuk mempengaruhi orang lain dalam organisasi.

\section{Motivasi Berafiliasi (Affiliation)}

Motivasi berafiliasi tercermin dalam keinginan seseorang untuk menciptakan, memelihara, dan menghubungkan suasana kebatinan dan perasaan yang saling menyenangkan antara sesama manusia dalam organisasi. Orang- orang yang memiliki kebutuhan tinggi untuk berafiliasi biasanya senang kasih sayang dan cenderung menghindari kekecewaan karena ditolak oleh suatu kelompok sosial. Tujuan utama dari orang dengan motivasi berafiliasi adalah memperoleh persahabatan dengan rekanya dalam organisasi, lebih menyukai situasi kooperatif daripada persaingan, dan sangat menyukai hubuanga yang melibatkan derajat pemahaman timbal balik yang tinggi. Bagi orang yang didominasi oleh motif ini disenangi eleh pimpinan dan rekan sekerja, dan pada umumnya orang yang demikian tidak terlalu mementingkan prestasi dalam organisasi melainkan lebih mementingkan persahabatan.

\section{Kinerja}

Mangkunegara dalam Tanuwibowo (2015) mengemukakan bahwa indikator kinerja, yaitu:

1. Kualitas kerja adalah seberapa baik seorang karyawan mengerjakan apa yang seharusnya dikerjakan.

2. Kuantitas kerja adalah seberapa lama seorang pegawai bekerja dalam satu harinya. Kuantitas kerja ini dapat dilihat dari kecepatan kerja setiap pegawai itu masing-masing.

3. Pelaksanaan tugas adalah seberapa jauh karyawan mampu melakukan pekerjaannya dengan akurat atau tidak ada kesalahan.

4. Tanggung jawab terhadap pekerjaan adalah kesadaran akan kewajiban karyawan untuk melaksanakan pekerjaan yang diberikan perusahaan. 


\section{Kerangka Pemikiran}

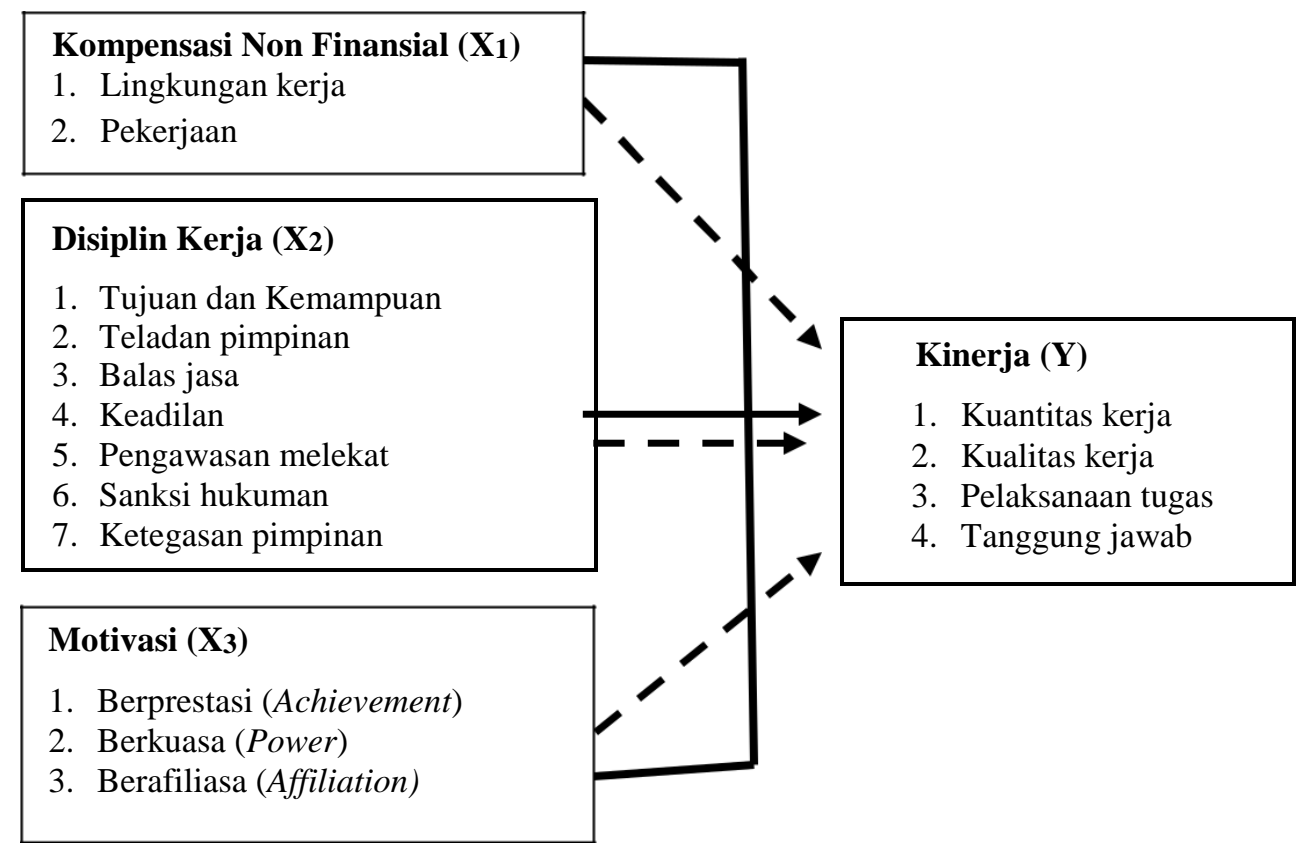

\section{Gambar 1 Kerangka Pemikiran}

\section{Hipotesis}

1. Kompensasi non finansial, disiplin kerja dan motivasi secara simultan mempunyai pengaruh signifikan terhadap kinerja pegawai di Kementerian Agama Kabupaten Donggala.

2. Kompensasi non finansial mempunyai pengaruh signifikan terhadap kinerja pegawai di Kementerian Agama Kabupaten Donggala.

3. Disiplin kerja mempunyai pengaruh signifikan terhadap kinerja pegawai di Kementerian Agama Kabupaten Donggala.

4. Motivasi mempunyai pengaruh parsial terhadap kinerja pegawai di Kementerian Agama Kabupaten Donggala.

\section{METODE PENELITIAN}

Penelitian ini menggunakan pendekatan kuantitatif. Populasi dalam penelitian ini adalah seluruh pegawai pada Kementerian Agama Kabupaten Donggala. Penarikan sampel dilakukan secara sensus, di mana semua unsur populasi dijadikan sampel penelitian sebanyak 36 orang. Selanjutnya analisis data menggunakan regresi lilier berganda yang bertujuan untuk mengetahui pengaruh variable bebas terhadap variable terikat, baik secara simultan maupun secara parsial.

\section{HASIL DAN PEMBAHASAN}

\section{HASIL PENELITIAN}

\section{Uji Regresi Linear Berganda}

Penelitian ini bertujuan untuk mengetahui besarnya pengaruh secara parsial antara Kompensasi Non Finansial, Disiplin Kerja dan Motivasi terhada Kinerja Pegawai Di Kementerian Agama Kabupaten Donggala. Serta untuk mengetahui variabel mana yang paling dominan berpengaruh terhadap kinerja pegawai di Kementerian Agama Kabupaten Donggala. 
Tabel 1 Hasil Perhitungan Regresi Linier Berganda

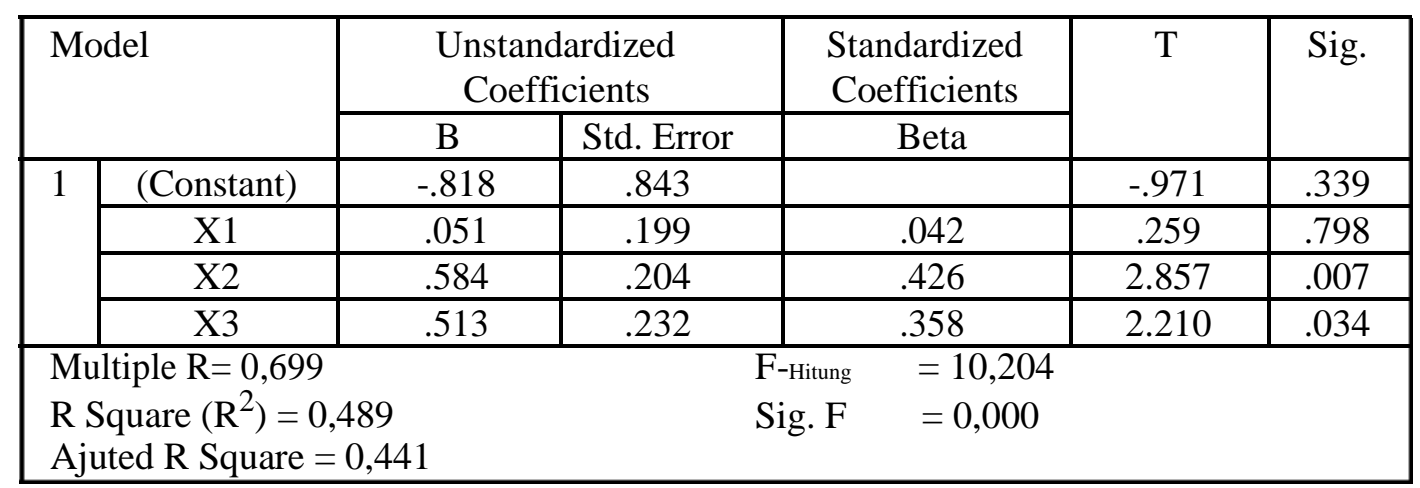

Berdasarkan nilai dari tabel di atas, maka persamaan regresi linear berganda dapat dirumuskan sebagai berikut:

$$
Y=-0,818+0,051 X 1+0,584 X 2+0,513 X_{3}
$$

Persamaan diatas menunjukan bahwa variabel independen (X1, X2 dan X3) memberi pengaruh negatif terhadap variabel dependen (Y). berdasarkan hasil rekapitulasi analisis regresi linier berganda di atas dapat dilihat pengaruh hasil uji determinan $\mathrm{R}$ square $\left(\mathrm{R}^{2}\right)$ sebesar 0,489 atau 48,9\%, jadi variabel $(\mathrm{X} 1, \mathrm{X} 2$, dan $\mathrm{X} 3)$ memiliki pengaruh terhadap kinerja pegawai sebesar 48,9\%. sedangkan sisanya dipengaruhi oleh variabel lain yang tidak diteliti. Adapun tingkat keeratan hubungan antara variabel independen terhadap variabel dependen yaitu kinerja pegawai pada Kementerian Agama Kabupaten Donggala melalui nilai Multiple $\mathrm{R}$ sebesar 0,699 atau 69,9\%. Melalui hasil multiple $R$ menujukan bahwa tingkat keeratan variabel sebesar 69,9\%. Sedangkan Ajusted $R$ square memiliki nilai sebesar 0,441 atau $44,1 \%$, yang menunjukan bahwa pengaruh variabel independen secara keseluruhan sebesar $44,1 \%$

1. Nilai konstanta sebesar $-0,818$ berarti apabila variabel kompensasi non finansial, disiplin kerja, dan motivasi nilainya 0 maka kinerja pegawai pada Kantor Kementerian agama Kabupaten Donggala tetap negative $-0,818$.

2. Kompensasi Non Finansial (X1) dengan koefisien regresi 0,051 tidak terjadi pengaruh yang signifikan antara kompensasi non finansial dan kinerja pegawai. Hal ini menunjukan bahwa meskipun nilai kompensasi non finansial meningkat tidak akan memberikan pengaruh yang signifikan terhadap kinerja pegawai pada Kantor Kementerian Agama Kabupaten Donggala.

3. Disiplin Kerja (X2) dengan koefisien regresi 0,584 , ini terjadi pengaruh yang signifikan antara disiplin kerja dan kinerja pegawai. Hal ini menyatakan bahwa nilai disiplin kerja meningkat maka akan meningkatkan kinerja pegawai pada Kantor Kementerian Agama Kabupaten Donggala.

4. Motivasi (X3) dengan koefisien regresi 0,513, Ini terjadi pengaruh yang signifikan antara motivasi dan kinerja pegawai. Hal ini menyatakan bahwa nilai motivasi meningkat maka akan meningkatkan kinerja pegawai pada Kantor Kementerian Agama Kabupaten Donggala.

\section{Uji F}

Uji F (serempak) adalah suatu metode untuk melihat apakah variabel independen (kompensasi non finansial, disiplin kerja dan motivasi) yang diteliti mempunyai pengaruh secara serempak terhadap variabel dependen (Kinerja). Untuk lebih jelasnya dapat dilihat pada tabel berikut: 
Tabel 2

Hasil Pengujian Serempak (Uji F)

ANOVA $^{\mathrm{a}}$

\begin{tabular}{|ll|r|r|r|r|r|}
\hline \multicolumn{2}{|l|}{ Model } & \multicolumn{1}{|c|}{$\begin{array}{c}\text { Sum of } \\
\text { Squares }\end{array}$} & Df & Mean Square & F & Sig. \\
\hline $1 \quad$ Regression & 7.999 & 3 & 2.666 & 10.204 & $.000^{\mathrm{b}}$ \\
& Residual & 8.362 & 32 & .261 & & \\
& Total & 16.360 & 35 & & & \\
\hline
\end{tabular}

Berdasarkan hasil uji regresi pada tabel di atas, diperoleh F-hitung sebesar 10.204 dengan tingkat signifikansi $0,000<0,05$, yang dapat diartikan bahwa variabel Kompensasi Non Finansial (X1) Disiplin Kerja (X2) dan Motivasi (X3) secara serempak berpengaruh signifikan terhadap variabel kinerja (Y). berdasarkan hasil tersebut dapat disimpulkan bahwa $\mathrm{H}_{0}$ ditolak dan $\mathrm{H}_{\mathrm{a}}$ diterima.

\section{UJI t}

Uji t digunakan untuk mengetahui apakah variabel independen yakni Kompensasi Non Finansial, disiplin Kerja dan motivasi yang diteliti memiliki pengaruh secara parsial terhadap variabel dependen yakni kinerja. Untuk lebih jelasnya dapat dilihat pada tabel berikut:

\section{Tabel 4 \\ Hasil Pengujian Parsial (Uji t) \\ Coefficients $^{\mathbf{a}}$}

\begin{tabular}{|c|c|c|c|c|c|c|}
\hline \multirow{2}{*}{\multicolumn{2}{|c|}{ Model }} & \multicolumn{2}{|c|}{$\begin{array}{l}\text { Unstandardized } \\
\text { Coefficients }\end{array}$} & \multirow{2}{*}{$\begin{array}{c}\text { Standardized } \\
\text { Coefficients } \\
\text { Beta } \\
\end{array}$} & \multirow[t]{2}{*}{$\mathrm{t}$} & \multirow[t]{2}{*}{ Sig. } \\
\hline & & B & Std. Error & & & \\
\hline \multirow[t]{4}{*}{1} & (Constant) & -.818 & .843 & & -.971 & .339 \\
\hline & $\mathrm{X} 1$ & .051 & .199 & .042 & .259 & .798 \\
\hline & $\mathrm{X} 2$ & .584 & .204 & .426 & 2.857 & .007 \\
\hline & X3 & .513 & .232 & .358 & 2.210 & .034 \\
\hline
\end{tabular}

\section{PEMBAHASAN}

\section{Disiplin Kerja dan Motivasi Terhadap Kinerja Pegawai}

Berdasarkan hasil penelitian yang telah dilakukan pada Kantor Kementerian Agama Kabupaten Donggala diketahui bahwa variabel disiplin kerja dan motivasi berpengaruh signifikan secara serempak terhadap kinerja pegawai pada Kantor Kementerian Agama Kabupaten Donggala. Hal ini mengambarkan bahwa Kantor Kementerian Agama Kabupaten Donggala sudah menerapkan disiplin kerja dan motivasi kerja yang baik bagi para pegawainya, dengan diterapkannya disiplin kerja dan motivasi kerja bagi para pegawai makan akan mempengaruhi kinerja dari seorang pegawai.

Variabel disiplin kerja dan motivasi kerja merupakan faktor yang mempengaruhi kinerja pegawai di Kantor Kementerian Agama Kabupaten Donggala. Dalam hal ini disiplin kerja mempengaruhi sikap ketaatan para pegawai dalam melakukan pekerjaan dan mentaati semua aturan yang telah ditetapkan. Sedangkan motivasi kerja mempengaruhi sikap pegawai untuk saling berinteraksi dengan pegawai lain dan selalu bertanggung jawab dengan tugas yg diberikan.

Berdasarkan hasil penelitian yang dilakukan menunjukan bahwa Kantor Kementerian Agama Kabupaten Donggala harus bisa mempertahankan kedua variabel babas yaitu disiplin kerja dan motivasi yang dimiliki paegawainya karena kedua variabel ini sudah berada pada interprestasi yang sangat baik atau sangat tinggi. Penelitian ini sejalan dengan penelitian yang dilakukan oleh 
(Marpaung, 2014) yang menyatakan bahwa disiplin kerja dan motivasi memiliki pengaruh yang signifikan terhadap kinerja pegawai.

\section{Kompensasi Non Finansial Terhadap Kinerja Pegawai}

Hasil penelitian yang dilakukan pada Kantor Kementerian Agama Kabupaten Donggala membuktikan bahwa kompensasi non finansial ada pengaruh tetapi tidak signifikan. Hal ini menunjukan bahwa meskipun pemberian kompensasi non finansial ditingkatkan tidak akan terjadi pengaruh yang signifikan antara kompensasi non finansial terhadap kinerja pegawai.

Hasil penelitian menunjukan bahwa lingkungan kerja yang ada di Kantor Kementerian Agama Kabupaten Donggala masih perlu diperhatikan terutama lingkungan yang ada di dalam ruangan. Dari penelitian yang dilakukan ruang kerja pegawai masih kurang luas, hal ini dilihat dari pegawai bekerja dalam satu ruangan terdiri dari empat orang. Ruang kerja seperti ini masih belum bisa menciptakan suasana tenang saat menjalankan tugas yang diberikan sehingga Kementerian Agama Kabupaten Donggala harus lebih memperhatikan kenyamanan pegawai terutama kenyamanan di dalam ruang kerja.

Meskipun dalam penelitian ini kompensasi non finansial memiliki pengaruh tidak signifikan Kementerian Agama Kabupaten Donggala tetap harus memperhatikan pemberian kompensasi non finansial, hal ini dilakukan demi untuk menciptakan kenyamanan pegawai saat melaksanakan tugastugas yang diberikan, selain itu pemberian kompensasi non finansial bertujuan untuk meningkatkat kinerja yang dimiliki pegawai.

\section{Disiplin Kerja Terhadap Kinerja Pegawai}

Hasil penelitian menunjukan bahwa besarnya pengaruh variabel bebas disiplin kerja yang terdiri dari tujuan dan kemampuan, teladan pimpinan, balas jasa, keadilan, pengawasan melekat, sanksi hukuman, dan ketegasan pimpinan terhadap variabel terikat yaitu kinerja pegawai. Penelitian yang dilakukan juga membuktikan bahwa semakin tinggi disiplin kerja yang diberikan maka kinerja pegawai juga meningkat. Dalam penelitian ini disiplin kerja berada pada interprestasi sangat baik atau sangaat tinggi sehingga diharapkan pada Kantor Kementerian Agama Kabupaten Donggala agar bisa mempertahankan disiplin kerja pegawainya. Uji analisis regresi membuktikan bahwa variabel bebas disiplin kerja berpengaruh signifikan terhadap variabel terikat yaitu kinerja pegawai. Penelitian ini sejalan dengan penelitian yang dilakukan oleh (Sopar Sihar Imanuel Siagian, 2015) bahwa disiplin kerja memiliki pengaruh terhadap peningkatan kinerja. Hasil ini memberikan makna bahwa semakin baik disiplin kerja pegawai maka kinerja pegawai juga semakin meningkat. Dari ketujuh dimensi disiplin kerja yang diantaranya adalah tujuan dan kemampuan, teladan pimpinan, balas jasa, keadilan, pengawasan melekat, sanksi hukuman, dan ketegasan pimpinan dimensi yang paling besar pengaruhnya adalah dimensi tujuan dan kemampuan. Dengan demikian pegawai Kantor Kementerian Agama Kabupaten Donggala menyadari akan pentingnya disiplin tujuan dan kemampuan dalam melaksanakan tugas sebagai seorang pegawai.

Kantor Kementerian Agama Kabupaten Donggala juga harus lebih memperhatikan disiplin kerja khususnya pada dimensi balas jasa, karena dimensi balas jasa memiliki nilai rata-rata yang paling rendah. Meskipun dimensi balas jasa sudah berada pada interprestasi yang baik atau tinggi, dimensi balas jasa masih bisa untuk ditingkatkan lagi sehingga dimensi balas jasa biasa berada pada interprestasi sangat baik atau sangat tinggai.

\section{Motivasi Terhadap Kinerja Pegawai}

Motivasi adalah pekerjaan yang memberikan dorongan atau rangsangan kepada pegawai agar bekerja dengan giat dan sunguh-sungguh untuk mencapai tujuan yang telah ditetapkan di Kantor Kementerian Agama Kabupaten Donggala. Berdasarkan hasil penelitian terbukti adanya pengaruh variabel bebas yaitu motivasi terhadap variabel terikat yaitu kinerja pegawai di Kementerian Agama Kabupaten Donggala. Dengan kata lain kedua variabel dalam konteks penelitian ini memiliki 
hubungan yang signifikan dimana motivasi sangat mempengaruhi kinerja pegawai. Indikator motivasi yang memiliki pengarung paling tinggi terhadap kinerja pegawai adalah indikator motivasi affiliation atau berafiliasi, hal ini dapat diartikan bahwa motivasi berafiliasi (affiliation) merupakan dimensi yang paling memotivasi pegawai untuk menunjukan kemampuan kerja mereka (indikator dominan membentuk variabel kinerja).

Signifikanya pengaruh motivasi terhadap kinerja juga didukung oleh dimensi achievement atau berprestasi, dimana pegawai yang bekerja di Kantor Kementerian Agama Kabupaten Donggala memiliki kesadaran dalam diri mereka masing-masing tentang pentingnya meningkatkan kinerja mereka agar tujuan organisasi dapat tercapai. Selain itu pegawai Kementerian Agama Kabupaten Donggala adalah tipe pegawai yang suka bekerja keras, dan memiliki kepercayaan diri dalam mengerjakan tugas yang diberikan. Dalam hal ini pegawai yang bekerja di Kantor Kementerian Agama Kabupaten Donggala mendapatkan motivasi yang baik dari atasan ke bawahan atau dari sesama rekan kerja. Hal ini dapat dilihat dari tingkat signifikanya variabel motivasi terhadap kinerja pegawai.

Faktor lain yang membuat motivasi berpengaruh signifikan terhadap kinerja pegawai adalah berkuasa (power). Tentu saja sebagai mahluk sosial akan selalu memiliki naluri untuk kekuasaan tidak terkecuali dalam diri pegawai Kementerian Agama Kabupaten Donggala. Pegawai merasa cukup memiliki tingkat kepemimpinan yang matang seperti pegawai lainnya, hal ini mereka tunjukan dengan maksud sebagai upaya menggagas perubahan kearah diri dan nasib kerja yang lebih baik, serta mampu mengenali sasaran-sasaran kerja yang bernilai tinggi. Paling tidak ada peningkatan karir yang sebanding dengan hasil kerja yang mereka lakukan.

Penelitian ini sejalan dengan penelitian yang dilakukan Khairul Hakim (2011) yang menyatakan motivasi memiliki pengaruh yang signifikan terhadap kinerja pegawai, bahwa semakin tinggi motivasi yang diberikan maka kinerja karyawan juga akan semakin meningkat.

\section{KESIMPULAN DAN}

\section{SARAN Kesimpulan}

1. Disiplin Kerja dan Motivasi secara simultan berpengaruh signifikan terhadap kinerja pegawai di Kantor Kementerian Agama Kabupaten Donggala.

2. Kompensasi Non Finansial secara parsial berpengaruh tidak signifikan terhadap kinerja pegawai di Kantor Kementerian Agama Kabupaten Donggala.

3. Disiplin Kerja secara parsial berpengaruh signifikan terhadap kinerja pegawai di Kantor Kementerian agama Kabupaten Dnggala.

4. Motivasi secara parsial berpengaruh signifikan terhadap kinerja pegawai di Kantor Kementerian Agama kabupaten Donggala.

\section{Saran}

Berdasarkan hasil penelitian yang dilakukan maka peneliti memberikan saran sebagai berikut:

1. Variabel kompensasi non finansial berpengaruh tidak signifikan terhadap kinerja pegawai pada Kantor Kementerian Agama Kabupaten Donggala. hal ini di karenakan dimensi pekerjaan masih terdapat variabel yang masih bisa untuk ditingkatkan agar berada pada interprestasi sangat baik. Dari hasil penelitian yang dilakukan diharapkan kepada Kantor Kementerian Agama Kabupaten Donggala untuk lebih meningkatkan variabel kompensasi non finansial khususnya pada dimensi pekerjaan.

2. Disiplin kerja yang ada pada Kantor Kementerian Agama Kabupaten Donggala sudah berada pada interprestasi yang sangat baik. Diharapkan Kantor kementerian Agama Kabupaten Donggala, disiplin kerja yang dimiliki pegawainya bisa dipertahankan. 
3. Motivasi kerja yang terdiri dari dimensi berprestasi, berkuasa dan berafiliasi yang ada di Kantor Kementerian Agama Kabupaten Donggala sudah berada pada interprestasi yang baik atau tinggi. Diharapkana motivasi kerja yang ada pada Kantor Kementerian Agama Kabupaten Donggala bisa dipertahankan, guna untuk menjaga agar kinerja pegawai tetap baik.

4. Kinerja pegawai yang ada di Kantor Kementerian Agama Kabupaten Donggala sudah berada pada interprestasi yang tinggi atau baik. Dalam penelitian ini Kantor Kementerian Agama Kabupaten Donggala yang saat ini memiliki kinerja pegawai baik atau tinggi bisa dipertahankan, Guna untuk menjaga kinerja pegawai agar tetap baik.

\section{REFERENSI}

Aminah siti, Eko Suprapto. (2017). Pengaruh Disiplin dan Kopetensi Terhadap Kinerja Bendahara SKPD di Kabupaten Meringin. Jurnal Ilmiah Batanghari Jambi, Vol.17, No. 1, 2017.

Bangun, Wilson. (2002). Manajemen Sumber Daya Manusia, Jakarta: PT. Glora Aksara Pratama. Hakim, A Khairul. (2011). Pengaruh Kompensasi dan Motivasi Terhadap Produktivitas Kerja

Pegawai. Jurnal Manajemen dan Bisnis, Vol.11, No.02.

Hasibuan, Melayu, SP. (2005). Manajemen Sumber Daya Manusia. Edisi Revisi Catatan Kedua.

Jakarta: PT. Bumi Aksara.

Heidjrachman dan Husnan. (2002). Manajemen Personalia. Yogyakarta: BPFE

Imanuel Siagian, Sopar Sihar. (2015). Pengaruh Pelatihan, Kepuasan Kompensasi,Motivasi dan Disiplin Kerja Terhadap Kinerja Karyawan. Jurnal Ilmu dan Riset Manajemen, Vol.4, No.9, 2015.

Marpoung, Iga Mawarni, Djamhur Hamid, dan Mohammad Iqbal. (2014). Pengaruh Motivasi dan Disiplin Kerja Terhadap Kinerja Karyawan Pada Rumah Sakit Reksa Waluya Mojokerto. Jurnal Administrasi Bisnis, Vol.15, No.2, Hal.1-8.

Rangkuti. (2006). Riset Pemasaran. Jakarta: PT. Gramedia Pustaka Utama.

Simamora, H. (2006). Manajemen Sumber Daya Manusia. Sekolah Tinggi Ilmu Ekonomi YKPN, Yogyakarta.

Simamora, H.( 2006). Manajemen Sumber Daya Manusia. Sekolah Tinggi Ilmu Ekonomi YKPN, Yogyakarta.

Simanjutak dan Calam. (2012). Pengaruh Kepemimpinan Transformasional dan Motivasi Terhadap Kinerja Karyawan PT.PLN (Persero) Cabang Binjai Wilayah Sumatra Utara. Dalam Jurnal Sintikom, Vol.11, No.2, Binjai : STIMIK Triguna Dharma Sumatra Utara.

Tanuwibowo Mitchael Hutomo dan Roy Setiawan. (2015). Pengaruh budaya organisasi dan motivasi kerja terhadap kinerja karyawan pada PT Lestari Purnama Perkasa. Agora, Vol. 3, No. 2. 